\title{
How Do Institutions Determine Economic Growth? Evidence from Central and Eastern Europe before and during Global Economic Crisis
}

\author{
Prof. Dr. Trajko Slaveski (Ss. Cyril and Methodius University, Macedonia) \\ Ph.D. Candidate Darko Lazarov (Goce Delchev University, Macedonia)
}

\begin{abstract}
We investigate the influence of institutions on economic growth and the level of income per capita in CEE region, before and during the global economic crisis. We use principal factor component analysis in order to create a more reliable and representative variable that will measure the institutional quality in our regression models, and avoid the multi colinearity, a common statistical weakness for this type of regression models. The results from panel (random and fixed effects) regressions and GMM dynamic panel regression lead to two contrasting insights. The first regression model shows positive and statistically significant correlation between institutions and economic growth, which would imply that the CEE countries that have created a strong institutional capacity during transition and post-transition period have experienced higher economic growth. The second regression model, which refers to the global economic crisis period, shows a negative influence of institutions on economic growth for the same sample of countries. One explanation for this result might be the fact that countries with a higher degree of integration into the EU were also more vulnerable to the global economic crisis.
\end{abstract}

\section{Introduction}

The panel econometric techniques have been applied on cross-country data for representative CEE countries, just to investigate the impact of institutions on economic growth and the level of income per capita before and during the global economic crisis. However, testing the correlation and causality between institutions and growth involves the difficult issue how to measure the quality of institutions.

Many international agencies and researchers have developed empirical indicators that claim to measure different aspects of institutional quality such as financial stability, quality of government regulations, democracy, quality of laws and courts, corruption, and many others. One of the key challenges confronting us in this empirical study, having in mind the large number of government and institutional indicators, is how to combine this set of indicators into one dimension with a clear-cut interpretation of quality of institutions and then analyze its impact upon income per capita and economic growth. The most widely used approach to construct composite variables is to select relevant indicators and weigh them together using predetermined weights. (This is what the WB and others providing these ratings do).

The empirical results estimated in this research lead to two contrasting insights. The first regression estimation by using fixed, random and GMM models for the transition and post-transition period shows positive and statistically significant correlation between the quality of institutions (composed by index of corruption, political rights and civil liberties) and economic growth derivate as logarithm of real GDP per capita, which would imply that the CEE countries that have created a strong institutional capacity during transition and post-transition period have experienced higher economic growth. The second regression model, which refers to the global economic crisis period, shows a negative influence of institutions on economic growth for the same sample of countries. One explanation for this result might be the fact that countries with a higher degree of integration into the EU were also more vulnerable to the global economic crisis.

\section{Literature Review}

Quite a few studies analyze the role of institutions in the process of economic growth. There are papers in the academic literature that investigate the influence of institutional quality on economic growth in the CEE region. Many of these studies are inspired by Hall and Jones (1999) who found a relation between institutional quality and economic growth for a large sample of countries. Beck and Laeven (2005) offer a political economy explanation of why institution building has varied so much across transition economies, using two major explanatory factors: reliance on natural resources and years under socialist government. This research is based on North's hypothesis that "institutions are not usually created to be socially efficient, but are created to serve the interests of those with bargaining power to create new rules" (North 1990). They conclude that countries with less open political systems in the transitional process and countries that have substantial natural resources have failed in development of the market-compatible institutions and consequently had slower economic growth in the transitional period. 
The research in this paper is directly linked to the literature on the relationship between institutions and economic growth and development. North (1981) emphasized the role of institutions for economic development. Acemoglu, Johnson and Robinson (2001) estimate large effects of institutions on income per capita by using differences in mortality rates of European settlers as an instrument for current institutions. Easterly and Levine (2003) show that institutions, not policies, explain the cross-country differences in GDP per capita once controlled for the impact of endowments on institutions and on economic development. Rodrik (2004) sheds some more light on the new institutional focus and the so called "second generation reforms". The agenda of new "government" reforms aimed at reducing corruption, improving the regulatory apparatus, rendering fiscal and monetary institutions independent, strengthening corporate governance, enhancing the function of the judiciary is meant to overcome the apparent inefficiency of the earlier wave of reforms relying heavily on liberalization, stabilization and privatization.

On the other hand, Bartlett and Prica (2012), investigating the transmission channels and mechanisms from the global crisis to SEE countries, find a negative correlation between institutions and economic growth during the economic crisis period, first because countries that have made the most progress in integrating with the EU and in adopting EU-compatible institutions were more vulnerable to the crisis. But, at the same time, these countries were better positioned to benefit from the recovery, since businesses in those countries operate within a more supportive institutional environment.

Over the past two decades the role and relationship between institutions and economic growth in transition countries have been of interest among many economists. In the table below we present the selected studies and their main findings.

\begin{tabular}{|c|c|c|c|}
\hline Study & Measures & Techniques & Main findings \\
\hline Paulo Mauro (1995) & $\begin{array}{l}\text { Bureaucratic efficiency index, } \\
\text { Political stability index and } \\
\text { Corruption index }\end{array}$ & $\begin{array}{l}\text { OLS and 2SLS } \\
\text { regression }\end{array}$ & $\begin{array}{l}\text { Find positive correlation } \\
\text { between high bureaucratic } \\
\text { efficiency and economic } \\
\text { growth, vice-versa. Positive } \\
\text { relationship between political } \\
\text { stability and growth, and } \\
\text { negative relationship between } \\
\text { index of corruption and } \\
\text { growth. }\end{array}$ \\
\hline $\begin{array}{l}\text { De Melo Martha, } \\
\text { Cevdet Denizer, and } \\
\text { Alan Gelb (1996) }\end{array}$ & $\begin{array}{l}\text { Index of liberalization for the } \\
\text { transition countries }\end{array}$ & $\begin{array}{l}\text { Panel } \\
\text { regression }\end{array}$ & $\begin{array}{l}\text { Find a positive relationship } \\
\text { between progress of } \\
\text { liberalization and output } \\
\text { growth }\end{array}$ \\
\hline $\begin{array}{l}\text { Aslund Anders, Peter } \\
\text { Boone, and Simon } \\
\text { Johnson, (1996) }\end{array}$ & $\begin{array}{l}\text { Structural and institutional } \\
\text { reforms for the CEE countries }\end{array}$ & $\begin{array}{l}\text { OLS and IV } \\
\text { regression }\end{array}$ & $\begin{array}{l}\text { Find no robust effect of } \\
\text { measures of reform and } \\
\text { macroeconomic policies on } \\
\text { output change }\end{array}$ \\
\hline Beck and Leaven (2005) & $\begin{array}{l}\text { Natural resources and the } \\
\text { historical experience of } \\
\text { Transition countries as } \\
\text { Instrumental variables }\end{array}$ & $\begin{array}{l}\text { Instrumental } \\
\text { variables - IV } \\
\text { regression }\end{array}$ & $\begin{array}{l}\text { Find positive relationship } \\
\text { between institutional } \\
\text { development and economic } \\
\text { growth }\end{array}$ \\
\hline $\begin{array}{l}\text { Will Bartlet and Ivana } \\
\text { Prica (2012) }\end{array}$ & $\begin{array}{l}\text { Institutional quality WGI and } \\
\text { Progress in transition - EBRD } \\
\text { transition index }\end{array}$ & OLS regression & $\begin{array}{l}\text { Negative correlation between } \\
\text { quality of institutions and } \\
\text { growth rate }\end{array}$ \\
\hline
\end{tabular}

Table.1 Literature review of institutions and economic growth

\section{Panel Regression Analysis of Institutions and Economic Growth in CEE Region}

\subsection{Data, Sources, Descriptive Statistics and Variables Description}

In our sample we use data for 13 countries from CEE region collected from many different sources. From Table. 2 we can see the arithmetic mean of the variables, standard deviation, minimum and maximum of the variables, and how many observations, panel and average time periods. The variables are: the level of GDP per capita; the rate of economic growth; the quality of institutions measured by the index of corruption, political rights and civil liberties, innovation capacity measured by royalty payments, general expenditure on research and development, and journal articles; human capital measured by gross enrolment in primary, secondary and tertiary education and education spending; export demand; bank credit to the private sector; openness as a share of total trade in GDP; investment rate; FDI; inflation rate; World Governance Indicators; and EBRD Transition Indicators. 


\begin{tabular}{|c|c|c|c|c|c|c|c|}
\hline & Variable & Mean & $\begin{array}{l}\text { Stand. } \\
\text { dev. }\end{array}$ & Min. & Max. & Obs. & \\
\hline LGDP & Log GDP per capita, US\$ & 8.08 & 0.74 & 6.09 & 9.51 & $\mathrm{~N}=$ & 124 \\
\hline $\begin{array}{l}\text { Economic } \\
\text { growth }\end{array}$ & $\begin{array}{l}\text { The rate of economic growth } \\
\text { per capita }\end{array}$ & 2.21 & 5.88 & $\overline{-}$ & 14.84 & $\mathrm{~N}=$ & 55 \\
\hline Institution & $\begin{array}{l}\text { Log of Institution quality } \\
\text { (Index of corruption, political } \\
\text { rights and civil liberties) }\end{array}$ & 0.53 & 0.71 & -2.38 & 1.20 & $\mathrm{~N}=$ & 122 \\
\hline Innovation & $\begin{array}{l}\text { Log of Innovation capacity } \\
\text { (Royal payments, GERD and } \\
\text { Journal articles) }\end{array}$ & -1.89 & 0.34 & -2.69 & -1.17 & $\mathrm{~N}=$ & 120 \\
\hline $\begin{array}{l}\text { Human } \\
\text { capital }\end{array}$ & $\begin{array}{l}\text { Log of Human capital (Gross } \\
\text { enrolment in primary, } \\
\text { secondary and } \begin{array}{l}\text { tertiary } \\
\text { education } \\
\text { spending) }\end{array}\end{array}$ & 3.86 & 0.11 & 3.57 & 4.08 & $\mathrm{~N}=$ & 135 \\
\hline Export & $\begin{array}{l}\text { Log of Export demand for } \\
\text { goods and services, US\$ }\end{array}$ & 18.14 & 1.59 & 13.92 & 21.09 & $\mathrm{~N}=$ & 135 \\
\hline Bank credit & $\begin{array}{l}\text { Log of Bank credit to private } \\
\text { sector, as } \% \text { of GDP }\end{array}$ & 3.05 & 0.71 & 1.25 & 4.48 & $\mathrm{~N}=$ & 131 \\
\hline Openness & $\begin{array}{l}\text { Openness (Export } \\
\text { Import), as a } \% \text { of GDP }\end{array}$ & 4.53 & 0.32 & 3.86 & 5.11 & $\mathrm{~N}=$ & 53 \\
\hline $\begin{array}{l}\text { Investment } \\
\text { Rate }\end{array}$ & Investment rate, as a \% of GDP & 3.17 & 0.25 & 2.34 & 3.68 & $\mathrm{~N}=$ & 50 \\
\hline FDI & Foreign direct investment & 17.25 & 1.44 & 13.69 & 20.46 & $\mathrm{~N}=$ & 51 \\
\hline Inflation Rate & Inflation rate, $\%$ & 1.54 & 0.60 & 0.04 & 2.72 & $\mathrm{~N}=$ & 53 \\
\hline WGI & World Governance Indicators & 0.29 & 0.40 & -0.27 & 0.986 & $\mathrm{~N}=$ & 50 \\
\hline EBRD Index & EBRD transition Index & 3.64 & 0.25 & 3 & 4.05 & $\mathrm{~N}=$ & 55 \\
\hline
\end{tabular}

Table.2 Descriptive statistics and variables description

\subsection{Methodology of Research}

In this paper we use panel data related to the countries in the sample. Because they are bound to heterogeneity in data for different countries, panel data estimation seems appropriate since it takes into account individual heterogeneity. Panel data are also more informative data; they include more variability, less colinearity and more efficiency. The question which researcher poses is which estimator to use: Random Effects Model, or Fixed Effects Model. Random Effects Model seems appropriate when we think that unobserved effect is uncorrelated with all of the explanatory variables. Estimation of Random Effects Model by Generalized Least Squares (OLS) is easy and routinely done by many econometric software packages. The basic model is as follows:

$$
y_{i t}=\beta_{0}+\beta_{1} x_{i t 1}+\beta_{2} x_{i t 2}+\beta_{k} x_{i t k}+a_{i}+u_{i t}
$$

The previous equation becomes RE model when unobserved effect $\boldsymbol{a}_{\boldsymbol{i}}$ is uncorrelated with all of the explanatory variables i.e. covariance is zero:

$$
\operatorname{Cov}\left(x_{i t n}, a_{i}\right)=0 \quad t=1,2, \ldots . T, n=1,2 \ldots k
$$

Now for the fixed effect if we have the following expression: $y_{i t}=a_{i}+\beta_{1} X_{i t}+u_{i t}, t=1,2 \ldots T$, for each crosssectional unit average, this equation becomes, $\bar{y}_{i t}=a_{i}+\beta_{1} \bar{X}_{i t}+\bar{u}_{i t}$, here $\bar{y}_{i t}=\frac{\sum_{t=1}^{T} y_{i t}}{T}$, if we subtract two previous equations (in order to eliminate the unobserved time constant) we get:

$$
y_{i t}-\bar{y}_{i t}=\beta_{1}\left(x_{i t}-\bar{x}_{i}\right)+u_{i t}-\bar{u}_{i}=\Delta y_{i t}=\beta_{1} \Delta x_{i t}+\Delta u_{i t}
$$

So the fixed effects estimator is efficient when idiosyncratic errors are serially uncorrelated, and there is no assumption about the correlation between the unobserved effect and the explanatory variables. Next, to test for the robustness of the results and to solve the endogenity problem, Dynamic panel data estimator namely Arelano/Bond GMM estimator is the most appropriate model, the basic model with lagged dependent variables is:

$$
y_{i t}=a_{i}+\gamma y_{i t-1}+u_{i t}, t=1,2 \ldots T
$$


In the previous equation residuals are assumed to follow normal distribution, i.e. $u_{i t}, \sim\left(0, \sigma_{u}^{2}\right)$. Here $y_{i t-1}$ depends positively on $\boldsymbol{a}_{\boldsymbol{i}}$, this is easy to see when we are inspecting the model for t-1 period:

$$
y_{i t-1}=a_{i}+y_{i t-2}+u_{i t-1}, t=1,2 \ldots T
$$

So there exist endogenity problem and OLS and GLS, i.e. FE and RE are not consistent. But the Arelano/Bond GMM estimator is consistent. The moment conditions use the properties of the instruments, and the instruments in the GMM Arelano /Bond model are the differenced explanatory variables:

$$
y_{i t-m} ; m \geq 2
$$

Now the instruments are uncorrelated with the future errors $u_{i t}$ and $u_{i t-1}$. The increasing number of moment of conditions is $t=3,4 \ldots T$. GMM estimation is combined with RE and FE estimator because as $T \rightarrow \infty$,estimates of the RE and FE model begin to converge.

\subsection{Econometric Model, Results and Explanations}

Since data cover 13 countries, and the period from 1993 to 2007, we apply panel estimation techniques. Panel data actually are cross-sectional data observed over time. The first econometric model that we estimate has the following structure:

$$
\ln \text { gdppercapita }=\gamma_{0}+\gamma_{1} \ln \text { Ins }+\gamma_{2} \log \text { Innov }+\gamma_{3} H u m+\gamma_{4} \log \text { Ex }+\gamma_{5} \text { Invest }+\varepsilon_{i}
$$

The left side of the equation articulates the economic growth derivate as logarithm of real GDP per capita as independent variable, expressed in terms of natural logarithm of GDP per capita in different time periods. On the right side are independent variables as determinants of economic growth for analysed group of CEE countries (institution quality measured by index of corruption, index of democracy, economic and civil liberties and political rights; innovation capacity measured by royalty payments, number of patents and journal articles and GERD; human capital measured by gross enrolment in primary, secondary and tertiary education, education spending and number of teachers per student); investment rate - private and public capital investment as a share of GDP; export as a percentage of real GDP; and bank credits to the domestic private sector as a percentage of GDP.

The results from the empirical study that we have partly done by using data for group of CEE countries in modified Panel econometric methods and OLS regression analysis show two controversial results. First, regression analysis which we use to estimate the first econometric model shows strong positive and statistical significant correlation between quality of institutions and economic growth in time series of 1993-2007 for the sample of CEE countries. But the second regression model which refers to the global economic crisis period shows negative correlation between institutional quality measured by WGI and EBRD Transition Indicators Index for the same sample of countries.

The first important question here is choosing an appropriate model for the estimation. The Breusch-Pagan LM test proved that there is significant difference of variance across countries i.e. we cannot use simple OLS, but rather Random effects model. But, the results from Hausman test is in favor of fixed effects model. Ambiguity of these two tests made us use the RE and FE models. Fixed effects model assumes that individual heterogeneity is captured by the intercept term, while Random effects model assumes that individual heterogeneity is captured by the intercept term and some random component. But, the coefficients of the variables in the two models are similar in size and they are of the same sign. The quality of institutions shows positive effect on economic performance during transition and post-transition period for all representative countries in our model, i.e. those countries which have implemented growth-promoting institutions (high level of transition progress to market economy, successful results in integration process to EU and adaptation to EU-compatible institutions, high quality of government policy making) have experienced a superior economic performance in the analyzed period.

Correlation between institutional quality and economic growth is relatively significant - an increase of institutional quality by 1 percent will contribute by 0.131 and 0.200 percent to the increase in the rate of economic growth, respectively in FE and GLS models.

The innovation capacity and human capital as fundamental factors of economic growth based on endogenous growth models have important role for economic growth, taking into consideration that the factor productivity and human capital were binding constraints, and the process of creation the National Innovation and Education System had positive implication in this group of countries. The regression results show that an increase of innovation capacity and human capital for $1 \%$ will increase the rate of economic growth for 0.124 and 1.149 , 
respectively with FE. The results are similar using the GLS model. These correlations are statistically significant at $95 \%$ and $99 \%$ trust's interval.

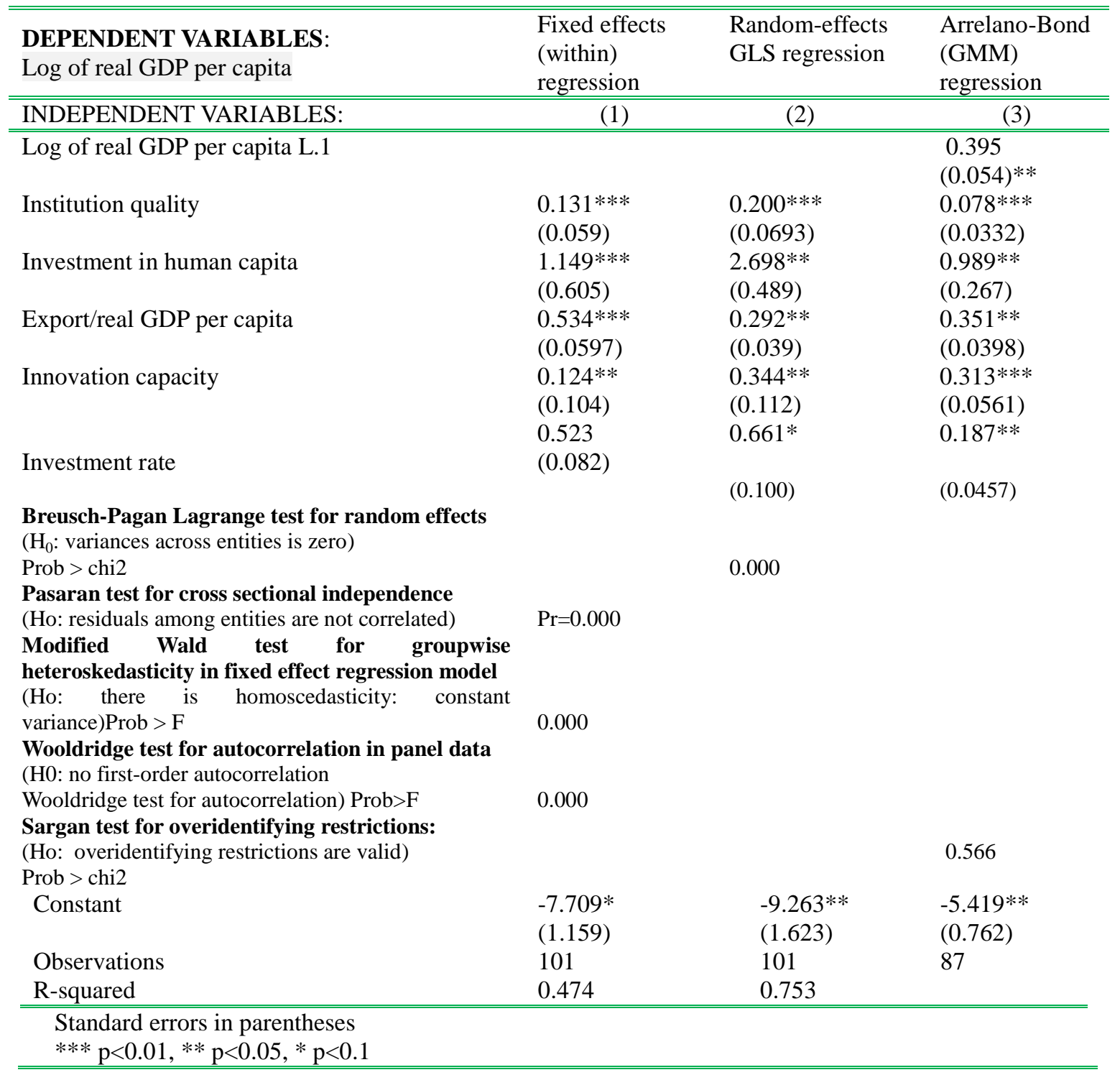

Table.3 Results for the Fixed and Random effects model, and Arrelano-Bond (GMM) regression

Most of the countries in our sample are small open economies and it is likely that there is positive and statistically significant link between export as a percent of real GDP and economic growth as a logarithm of real GDP per capita. Growth in openness measured by export share in GDP would make the economic growth more dynamic for $0.534 \%$ with a level statistical significance, p-value 0.000). Bank credits to the private sector as a main source for financing investment in CEE counties have important role for economic growth. Countries with market oriented financial sector which give support to private sector and businesses have better chance for economic growth. This conclusion can be proved by econometric results that we have obtained, efficiency of the financial sector presented by bank credit to private sector is positively and statistically significant correlated with economic growth in our sample of countries over the period (1992-2007).

The most serious problems that we have addressed in the FE model (by Pasaran and modified Wald test) are the present of cross sectional independence (the correlation of residual among entities) i.e. contemporaneous correlation and groupwise heteroskedasticity (not constant variance). We used Driscoll-Kraay standard errors to overcome the contemporaneous correlation and robust standard errors to overcome the heteroskedasticity.

Our estimation might be biased due to counties' fixed effects and endogenity problems on the explanatory variables. We tackle these issues by including internal instruments (GMM). The Sargan test for over identifying restrictions do not reject the null hypothesis that our instruments are appropriate, indicate that the GMM estimation is consistent. Additionally, the comparison of Columns (1) with fixed effects, (2) with random effects, and (3) with GMM allows us to identify that the use of the GMM estimators confirm the positive impact of institutional quality on economic growth. While the coefficient on institutional quality obtained with the GMM 
estimator appears smaller, it is not significantly different from the one obtained based on fixed and random effects. This suggests that our indicator does not suffer from endogeneity problems. The strong link between export sophistication and growth does not appear to be driven by simultaneity bias.

\section{Institutions and Economic Growth in CEE Region during Global Economic Crisis}

The process of EU integration has required building a strong institutional capacity with new institutions appropriate to EU standards such as competition agencies, reform in the existing institutions and many others. The pre-condition for this process is harmonization of the system of laws to the acquis communautaire. There are many studies which have shown that the progress in EU integration has a positive effect on institutional quality measured by EBRD Transition Indicators and World Governance Indicators on one side, and the quality of institutions and economic growth, on the other. Consequently, countries which have made significant progress in adopting EU-compatible and market oriented reforms in the period before the crisis and as a result have become EU members, have had a higher average economic growth. However, the central issue in this paper is how institutions influence economic growth during global economic crisis period in this region?

\begin{tabular}{|l|l|c|c|c|}
\hline & \multicolumn{1}{|c|}{ Country } & $\begin{array}{c}\text { Average } \\
\text { GDP growth } \\
\mathbf{2 0 0 8 - 2 0 1 1}\end{array}$ & WGI & $\begin{array}{c}\text { EBRD } \\
\text { Index }\end{array}$ \\
\hline EU Membership & $\begin{array}{l}|c| \\
\text { Bulgaria, Croatia, Hungary, Latvia, } \\
\text { Romania, Slovenia }\end{array}$ & -0.37 & 0.53 & 3.74 \\
\hline Non-EU Members & Albania, Macedonia, Serbia, Turkey & 2.39 & -0.11 & 3.39 \\
\hline
\end{tabular}

Table.4 EU membership, the average GDP growth, WGI and EBRD index

Table 4. above shows that EU member countries with higher quality of institutions measured by EBRD Transition Indicators Index and WGI were adversely affected by the economic crisis with negative average rate of economic growth $(-0.37 \%)$. On the other side, countries which have lagged in EU integration process and in the process of strengthening the institutional capacity were not seriously affected by the crisis. The average rate of economic growth of non-EU members (2.39\%) during economic crisis was significantly higher than the average growth of EU member countries.

The second regression model that we have estimated uses different set of variables to represent the quality of institutions (WGI, EBRD Transition Indicators, EU integration), for the time period during global economic crisis. The econometric equations that we estimate have the following structure:

$$
\begin{aligned}
& g=\gamma_{0}+\gamma_{1} \text { WGI }+\gamma_{2} \text { Openn }+\gamma_{3} \text { Inf }+\gamma_{4} \text { Invest }+\gamma_{5} \text { FDI }+\varepsilon_{i} \\
& g=\gamma_{0}+\gamma_{1} \text { EBRDIndex }+\gamma_{2} \text { Openn }+\gamma_{3} \text { Inf }+\gamma_{4} \text { Invest }+\gamma_{5} F D I+\varepsilon_{i}
\end{aligned}
$$

\begin{tabular}{|c|c|c|c|c|}
\hline $\begin{array}{l}\text { DEPENDENT VARIABLES: Economic } \\
\text { growth per capita }\end{array}$ & $\begin{array}{l}\text { (1) } \\
\text { OLS Panel } \\
\text { regression }\end{array}$ & $\begin{array}{l}\text { (2) } \\
\text { Random- } \\
\text { effects GLS } \\
\text { regression }\end{array}$ & $\begin{array}{l}\text { (3) } \\
\text { OLS Panel } \\
\text { regression }\end{array}$ & $\begin{array}{l}\text { (4) } \\
\text { Random- } \\
\text { effects GLS } \\
\text { regression }\end{array}$ \\
\hline \multicolumn{5}{|l|}{ INDEPENDENT VARIABLES: } \\
\hline Openness & $\begin{array}{l}0.0940 * * \\
(0.0366)\end{array}$ & $\begin{array}{l}0.134 * * * \\
(0.0441)\end{array}$ & $\begin{array}{l}0.0399 \\
(0.0293)\end{array}$ & $\begin{array}{l}0.0588 \\
(0.0360)\end{array}$ \\
\hline Inflation & $\begin{array}{l}-0.328 \\
(1.278)\end{array}$ & $\begin{array}{l}-1.445 \\
(1.433)\end{array}$ & $\begin{array}{l}-0.314 \\
(1.401)\end{array}$ & $\begin{array}{l}-1.283 \\
(1.543)\end{array}$ \\
\hline FDI & $\begin{array}{l}1.654 * * \\
(0.739)\end{array}$ & $\begin{array}{l}2.094 * * \\
(0.880)\end{array}$ & $\begin{array}{l}0.608 \\
(0.661)\end{array}$ & $\begin{array}{l}0.807 \\
(0.771)\end{array}$ \\
\hline Investment & $\begin{array}{l}6.449 * * \\
(3.063)\end{array}$ & $\begin{array}{l}7.711 * * \\
(3.557)\end{array}$ & $\begin{array}{l}8.852 * * * \\
(3.034)\end{array}$ & $\begin{array}{l}10.83 * * * \\
(3.448)\end{array}$ \\
\hline WGI & $\begin{array}{l}-1.931 * * * \\
(2.357)\end{array}$ & $\begin{array}{l}-3.441 * * * \\
(3.099)\end{array}$ & & \\
\hline EBRD Index & & & $\begin{array}{l}-1.585^{* * * *} \\
(3.798)\end{array}$ & $\begin{array}{l}-3.083 * * * \\
(4.868)\end{array}$ \\
\hline Constant & $\begin{array}{l}-53.79 * * * \\
(13.79)\end{array}$ & $\begin{array}{l}-66.82 * * * \\
(14.73)\end{array}$ & $\begin{array}{l}-33.58 * * \\
(15.80)\end{array}$ & $\begin{array}{l}-38.31 * \\
(19.68)\end{array}$ \\
\hline Observations & 64 & 62 & 66 & 64 \\
\hline R-squared & 0.456 & 0.583 & 0.358 & 0.409 \\
\hline
\end{tabular}

Table.5 Results for the OLS, fixed and random effects model estimation for the second model 
The results show that the quality of institutions measured by the WGI and the EBRD Transition Indicators has had a negative impact on economic growth during global economic crisis period, which is at least controversial. The logical explanation of the negative impact of institutional quality rests upon the fact that countries in the CEE region which have made the most significant institutional progress by integration to the EU were more vulnerable to the crisis. This sensitivity and vulnerability to the crisis primarily came from the higher degree of openness to the transmission effects through financial flows and falling export demand. But, at the same time they have better chance to overcome the crisis and better opportunities for recovering their economies, since private sector in those countries operate within a more supportive and market oriented institutional environment.

The regression results show negative correlation between institutional quality measured by World Government Indicators (voice and accountability, political stability and absence of violence, rule of laws, index of corruption, government efficiency and regulatory quality) and EBRD transitional index (large and small scale privatization, governance and enterprise restructuring, price liberalization, trade and foreign exchange system and competition policy) and economic growth in the period during the world financial and economic crisis.

The graphical presentation on a scatter plot visualizes the negative partial correlation and interdependence between institutional quality measured by WGI and the rate of economic growth over the global economic crisis period. The countries that have succeeded in the creation of comprehensive and EU-compatible institutional environment were more sensible to the shocks as a result of global economic crisis, and vice-versa. Slovenia, Latvia, Croatia, Bulgaria and Romania as countries with higher degree of financial and EU integration have had a slower economic growth compared to the Republic of Macedonia, Serbia, Turkey, Russia and Albania.

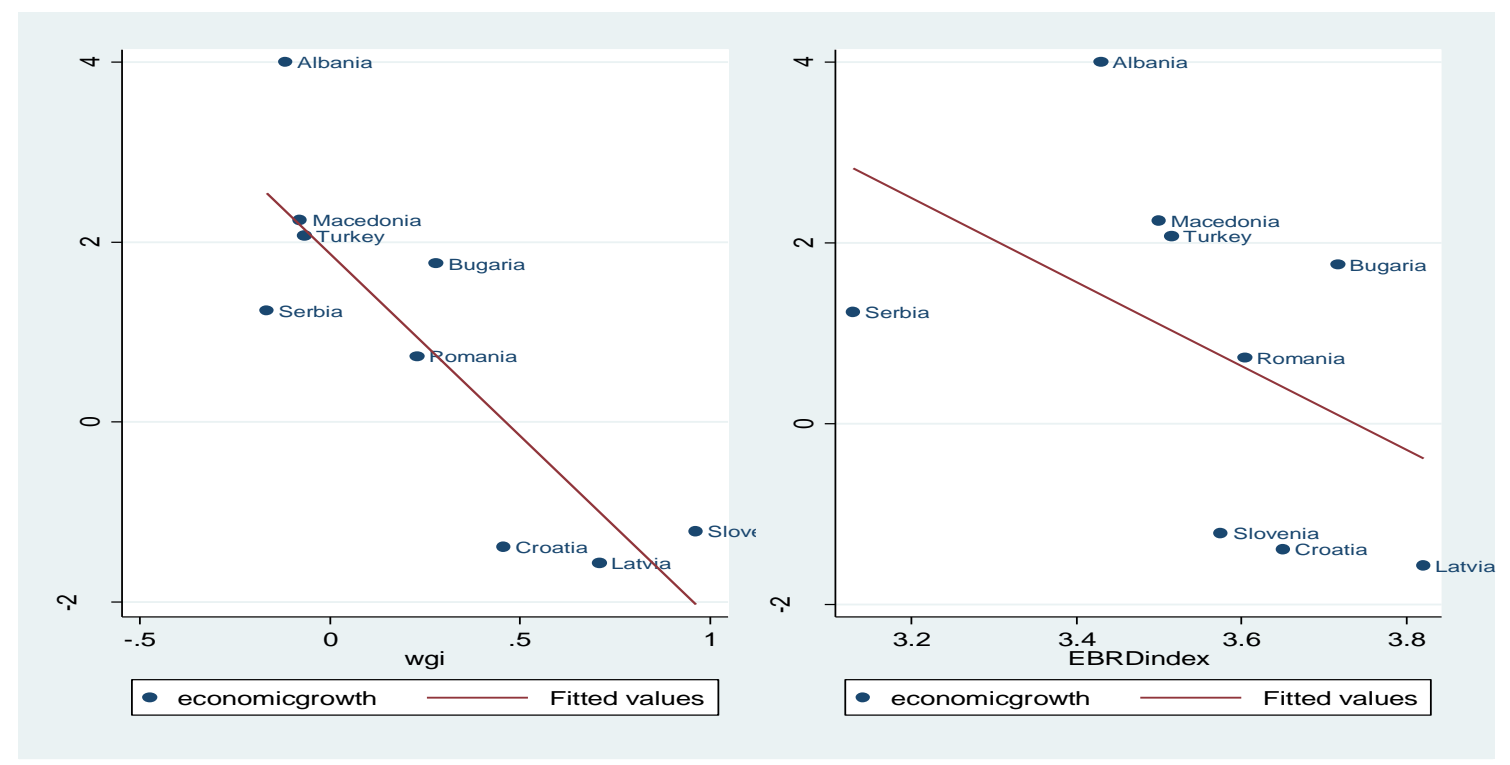

Figure 1. Average economic growth and quality of institutions during global economic crisis

\section{References}

- Acemoglu, Daron, Simon Johnson, and James A. Robinson. 2001. The colonial origins of

- Comparative development: An empirical investigation. American Economic Review 91.

- Arellano, Manuel \& Bond, Stephen, (1991), Some Tests of Specification for Panel Data: Monte Carlo Evidence and an Application to Employment Equations, Review of Economic Studies, Wiley Blackwell, vol. 58(2), pages 277-97, April.

- Bartlett, W., Prica, I. 2011. The variable impact of the global economic crisis in South East Europe. LSEE Research on South Eastern Europe.

- $\quad$ Beck, Thorsten \& Laeven, Luc. 2005. Institution building and growth in transition economies. Policy Research Working Paper Series 3657, The World Bank series.

- Rodrik, Dani. 2008. "Second-Best Institutions," American Economic Review, Papers and Proceedings, May.

- Easterly, William and Ross Levine. 2003. Tropics, germs, and crops: The role of endowments in economic development. Journal of Mon

- EBRD index http://www.ebrd.com/pages/research/economics/data/macro.shtml.

- Fulvio Castellacci and Jose Miguel Natera: A new panel dataset for cross-country analyses of national systems, growth and development (CANA), working paper. 
- Gujarati, Damodar N. .2003. Basic Econometrics. New York: McGraw-Hill.

- Mankiw, N. Gregory, David Romer, and David N. Weil. 1992. A contribution to the empirics of economic growth. Quarterly Journal of Economics 107:407-37.

- Petreski. Goce and Lazarov, Darko. 2013. The impact of global economic crisis in SEE, ASECU.

- $\quad$ Robert E. Hall and Charles J. Jones.1999. Why do some countries produce so much more output than others? Quarterly Journal of Economics, 114, pp. 83-116.

- World Bank.2013. World Development Indicators.

- Wooldridge, Jeffrey. 2002. Introductory Econometrics: A Modern Approach, Thomson.

- Wooldridge, Jeffrey.2002. Econometric Analysis of Cross Section and Panel Data, MIT Press.

- World Bank data base, http://data.worldbank.org/indicator,

- WorldWide Governance Indicators http://info.worldbank.org/governance/wgi/index.aspx\#home 